\title{
Q\&A
}

\section{China coronavirus: what do we know so far?}

\author{
Elisabeth Mahase
}

The BMJ

Since reports of a mysterious pneumonia-like condition began circulating in December, the public health world has been keeping its eye on the events unfolding in China. ${ }^{1}$ As the numbers of confirmed cases and deaths have risen, details of the novel coronavirus now known as 2019-nCoV have dripped through. Here's what we know so far about this evolving situation.

\section{Where did it start?}

The initial source of 2019-nCoV is still unknown, but the first cases were linked to a seafood market in the city of Wuhan, capital of the central Hubei province. The market was closed on 1 January 2020 as part of efforts to contain the outbreak. ${ }^{2}$

\section{How many cases of the infection have been confirmed?}

As at 24 January 830 cases and 26 deaths had been confirmed worldwide. ${ }^{3}$ Of the confirmed cases, around $25 \%$ are thought to be severe. Outside mainland China cases have been confirmed in Thailand, Japan, Hong Kong, Taiwan, South Korea, and the US. Cases had been reported in the UK but not yet confirmed.

\section{Is the actual number of cases likely to be much higher?}

The MRC Centre for Global Infectious Disease Analysis at Imperial College London has estimated that by 18 January 4000 people in Wuhan should have shown symptoms caused by the novel disease (uncertainty range 1000 to 9700 ). ${ }^{4}$ Their estimate was based on the population, travel patterns, and predicted transmission of the virus.

\section{Can the virus spread from person to person?}

Yes, human to human transmission has been confirmed. The World Health Organization said that the preliminary R0 (reproduction number) estimate is 1.4 to 2.5 , meaning that every person infected could infect between 1.4 and 2.5 people.

\section{How does it compare with SARS or MERS?}

The virus is a type of coronavirus, a family that includes the common cold, severe acute respiratory syndrome (SARS), and Middle East respiratory syndrome (MERS). MERS was first identified in Saudi Arabia in 2012, and around 34\% of people reported as infected with the virus have died ( 858 of 2494 cases). ${ }^{5}$ Its R0 is less than one. ${ }^{6}$ The SARS outbreak of 2002-03 led to 8098 identified cases and 774 deaths $(9.6 \%)$. It has an R0 of $2-5$. $^{7}$

\section{What's the death rate?}

The case fatality rate of 2019-nCoV infection has been fluctuating as new information comes to light. On 23 January the World Health Organization estimated it at 4\% (17 of 557 cases). However, as at 24 January it could be around 3\% (26 of 830). Peter Piot, professor of global health and director of the London School of Hygiene and Tropical Medicine, said, "The good news is that the data to date suggest that this virus may have a lower mortality than SARS, we have a diagnostic test, and there is greater transparency than in decades gone by. And that is essential, because you cannot deal with a potential pandemic in one country alone."

\section{Were lessons learnt from the SARS pandemic?}

Diana Bell, from the University of East Anglia's School of Biological Sciences, said that after SARS there was an emphasis on wildlife trade as a "major dual threat to human health and a primary cause of biodiversity decline in China and South East Asia." However, she said that the warnings have clearly not been heeded.

But Paul Hunter, professor in medicine at UEA, thinks there has been some improvement. He said that Chinese authorities had been "much more open about the outbreak, investigated the infection much more rapidly and thoroughly, and shared that information with the international community ... As a result of this increased openness and better management, neighbouring countries should be able to prepare well in advance of any cases that may arrive on their shores." 


\section{What action has been taken in China?}

Chinese authorities have imposed travel bans on several Chinese cities near Wuhan, affecting more than 41 million people. The ban came as people were preparing for Chinese New Year, which falls on Saturday 25 January. The New Year celebrations involve a 40 day period when many people travel to home towns and villages to celebrate with their families. An estimated three billion trips were made in the period last year. ${ }^{8}$

Michael Head, senior research fellow in global health at the University of Southampton, called the restrictions "unprecedented" and raised concerns over the effects on people inside the quarantine zones. "Will they have enough food to eat? How will their health facilities operate? Will people still go to their doctors and hospitals? How are emergency cases going to be treated? Will the hospitals have any medicines left? These are all questions China will be considering right now," he said.

The New York Times has reported that residents in Wuhan are nervous and angry about the restrictions. Doctors have also reportedly raised concerns about a shortage of hospital beds and testing kits. ${ }^{9}$

\section{How are other countries responding?}

Many countries, including the UK, have implemented screening at borders or on board for flights coming from the affected region in China. However, experts have warned that this measure cannot be seen as a "catch all," as people may be infected but arrive without symptoms. ${ }^{10}$ A diagnostic test has been developed, and countries are quarantining and testing suspected cases. In the UK people who have been to Wuhan in the past 14 days and have developed respiratory symptoms are being advised to phone NHS 111.

\section{What's the advice for healthcare workers?}

In England, NHS staff are being told to ensure that they take an accurate travel history from all patients with acute respiratory infections to help identify potential cases. GPs are being asked to identify possible cases, isolate the patients immediately, and seek specialist advice from a microbiologist, virologist, or infectious disease doctor at their local trust. ${ }^{11}$ To learn more see the BMJ Best Practice module. ${ }^{12}$

\section{Is this an international emergency?}

WHO met on 22-23 January to determine whether the situation should be deemed a public health emergency of international concern but decided against it. However, the committee will reconvene "in a matter of days to examine the situation further." Many believe it's only a matter of time that an emergency is declared.

Correction: On 3 February we corrected the first sentence under "What's the death rate?" to "case fatality rate" (not "mortality rate"). Thanks to Thomas Hanscheid for the rapid response pointing out our error.

Seven days in medicine: 8-14 Jan 2020. BMJ 2020;368:m132.31948945

2 World Health Organization. Novel Coronavirus (2019-nCoV) situation reports. https://www. who.int/emergencies/diseases/novel-coronavirus-2019/situation-reports.

3 China coronavirus: Death toll rises as more cities restrict travel. BBC News. https://www. bbc.co.uk/news/world-asia-china-51230011.

4 Imperial College London. Report 2: estimating the potential total number of novel coronavirus cases in Wuhan City, China. Jan 2020. https://www.imperial.ac.uk/mrc-globalinfectious-disease-analysis/news--wuhan-coronavirus.

5 World Health Organization. Middle East respiratory syndrome coronavirus (MERS-CoV). https://www.who.int/en/news-room/fact-sheets/detail/middle-east-respiratory-syndromecoronavirus-(mers-cov).

6 World Health Organization. WHO MERS global summary and assessment of risk. Aug 2018. https://www.who.int/csr/disease/coronavirus_infections/risk-assessment-august2018.pd

7 World Health Organization. Consensus document on the epidemiology of severe acute respiratory syndrome (SARS). https://www.who.int/csr/sars/en/WHOconsensus.pdf.

8 Cripps K, Wang S. World's largest annual human migration now underway in China. CNN Jan 2019. https://edition.cnn.com/travel/article/lunar-new-year-travel-rush-2019/index. html.

9 Coronavirus death toll climbs in China, and a lockdown widens. New York Times. Jan 2020. https://www.nytimes.com/2020/01/23/world/asia/china-coronavirus.html?campaign id=60\&instance_id=0\&segment_id=20565\&user_id=18a4c5248f00e94211664d0a29f66f1 d\& regi_id=87733833\#link-14aa6667

10 Mahase E. Coronavirus: UK screens direct flights from Wuhan after US case. BMJ 2020;368:m265. 10.1136/bmj.m265 31969317

11 Public Health England. WN-CoV: Interim guidance for primary care. Jan 2020. https:// www.gov.uk/government/publications/wn-cov-guidance-for-primary-care/wn-cov-interimguidance-for-primary-care

12 WN-CoV. Interim guidance for primary care. BMJ Best Practice. Jan 2020. https:// bestpractice.bmj.com/topics/en-gb/3000165.

Published by the BMJ Publishing Group Limited. For permission to use (where not already granted under a licence) please go to http://group.bmj.com/group/rights-licensing/ permissions 